\title{
ANALISIS DETERMINAN KUALITAS HIDUP PADA PASIEN DENGAN HIPERTENSI DERAJAT II
}

Studi Pada Pasien Hipertensi Derajat II di Puskesmas Dinoyo Kota Malang

\author{
Nurma Afiani \\ Prodi Ilmu Keperawatan STIKES Widyagama Husada \\ nurmaafiani@gmail.com
}

\begin{abstract}
Controlling over the factors that affect the life quality of patients suffer from hypertension stage II is necessary to prevent the occurrence of hypertensive crisis and other cardiovascular complications. This study was conducted in order to identify the factors influencing the life quality of patients with hypertension stage II. An analytic-observational study was done upon hypertension outpatients at Dinoyo Community Health Centers in Malang from Mei to July 2014. The subjects of the study were the hypertension stage II patients who had filled in the Informed Consent Form. Compliance was assessed using MMAS (Morisky Medication Adherence Scale) questionnaire and the SF-36 (Short Form-36) questionnaire. Furthermore, the data dealing with the factors influencing the compliance and the life quality of the patients with hypertension stage II were analyzed using Path Analysis. From out of 853 outpatients visiting the Out Patients Departement (OPD), there were 50 subjects who were eligible in this study. It was found that based on the Path Analysis, the direct factors that influenced the quality of life were: 1$)$ compliance $(r=0.401 ; p=0.000) ; 2)$ economic level $(r=0.257 ; p=0.009)$; and 3) antihypertensive $(r=0.159 ; p=0.016)$. In addition, there were some factors that influenced compliance to treatment, they were: 1) economic level $(r=0.239 ; p=0.004)$ and 2$)$ educational level $(r=0.237 ; p=0.000)$. It can be concluded that economic and educational levels affected the compliance that indirectly gave impact to the life quality of patients with hypertension stage II.
\end{abstract}

Keywords: Compliance, Quality of Life, Hypertension Stage II 


\begin{abstract}
Abstrak
Hipertensi derajat II tidak terkontrol dapat beresiko menimbulkan krisis hipertensi dan penyakit kardiovaskular lain, serta menurunkan kualitas hidup penderita. Oleh karena itu, kontrol terhadap faktor-faktor yang mempengaruhi kualitas hidup penderita hipertensi derajat II diperlukan untuk mencegah terjadinya krisis hipertensi dan komplikasi kardiovaskular lain. Tujuan penelitian ini adalah untuk mengidentifikasi faktor-faktor yang dapat mempengaruhi kualitas hidup penderita hipertensi derajat II dengan mengimplementasikan studi analitik observasional yang dilakukan pada pasien hipertensi rawat jalan di Poliklinik Umum Puskesmas Dinoyo Kota Malang selama bulan Mei sampai Juli 2014. Subjek dipilih sesuai dengan kriteria hipertensi derajat II dan yang telah mengisi blanko Informed Consent. Data tentang kepatuhan terapi dan kualitas hidup diperoleh dari hasil wawancara masing-masing pasien dengan menggunakan kuisioner MMAS (Morisky Medication Adherence Scale) dan SF-36 (Short Form-36). Faktor-faktor yang mempengaruhi kualitas hidup penderita hipertensi derajat II lainnya dikaji dan dianalisa dengan analisis jalur (Path Analysis). Berdasarkan hasil analisa jalur, ditemukan bahwa faktor-faktor yang berpengaruh langsung terhadap kualitas hidup berturut-turut adalah kepatuhan terapi $(\mathrm{r}=0.401 ; \mathrm{p}=0.000)$, tingkat ekonomi $(\mathrm{r}=0.257 ; \mathrm{p}=0.009)$ dan jenis antihipertensi $(\mathrm{r}=0.159$; $\mathrm{p}=0.016)$. Kepatuhan terapi sendiri juga dipengaruhi oleh beberapa faktor yaitu tingkat ekonomi ( $\mathrm{r}=0.239 ; \mathrm{p}=0.004)$ dan tingkat pendidikan $(\mathrm{r}=0.237 ; \mathrm{p}=0.000)$. Jadi, faktor ekonomi dan pendidikan merupakan faktor yang paling dominan dalam menentukan kepatuhan terapi yang kemudian berdampak kepada kualitas hidup.
\end{abstract}

Kata Kunci: Kepatuhan Terapi, Kualitas Hidup, Hipertensi Derajat II

\section{PENDAHULUAN}

Penyakit kardiovaskular merupakan penyebab kematian paling banyak di negara berkembang serta menjadi penyebab kecacatan dan kematian utama di negara maju (Whelton et al., 2004). Pada tahun 2000, jumlah penderita hipertensi mencapai $26 \%$ dari total penduduk dunia dan diperkirakan akan mencapai $>29 \%$ atau sekitar 1.56 milyar pada tahun 2025 (Iqbal, 2011; WHO, 2012).

Laporan JNC 7 menyebutkan bahwa jumlah penderita hipertensi terkontrol kurang dari 50\%, jumlah penderita hipertensi tidak terkontrol $30 \%$ dan sisanya tidak mengetahui bahwa mereka mengalami hipertensi (Chobanian, 2003). Hipertensi tidak terkontrol cenderung berkembang menjadi hipertensi derajat II serta dapat meningkatkan resiko terjadinya krisis hipertensi dan penyakit kardiovaskular lain (Franklin \& Neutel, 2009).

Terapi antihipertensi merupakan unsur utama dalam pengelolaan hipertensi derajat II (Chobanian, 2003). Konsumsi antihipertensi pada penderita hipertensi derajat II secara tepat dapat menurunkan resiko terjadinya penyakit kardiovaskular lain serta dapat mencegah berkembangnya hipertensi ringan dan sedang menjadi hipertensi derajat II (Franklin \& Neutel, 2009).

Kepatuhan terhadap terapi antihipertensi merupakan salah satu unsur penting dalam pengelolaan hipertensi (Nunes, 2001). Penatalaksanaan hipertensi yang baik dapat mengurangi resiko terjadinya stroke, penyakit kardiovaskular lain dan penyakit ginjal (Hacihasanoglu et al., 2012). Melalui pengelolaan 
hipertensi yang baik diharapkan penderita hipertensi berhasil mencapai target terapi. Keberhasilan terapi hipertensi tidak hanya dipengaruhi oleh ketepatan diagnosa, pemilihan dan pemberian obat yang tepat, namun kepatuhan konsumsi obat juga merupakan salah satu unsur penting dalam kontrol hipertensi.

Kepatuhan terhadap terapi dapat mempengaruhi kualitas hidup seseorang dengan penyakit kronis (Saleem et al., 2012). Hipertensi sebagai salah satu penyakit kronis memerlukan kontrol terapi seumur hidup untuk mencegah berkembangnya penyakit kardiovaskular lain pada penderita. Hipertensi sering dikaitkan dengan kualitas hidup yang rendah serta menjadi faktor resiko utama terjadinya penyakit kardiovaskular lain. Saleem et al. (2012) menyebutkan bahwa kepatuhan yang rendah terhadap program terapi dapat meningkatkan resiko kekambuhan dan meningkatkan peluang rawat inap di rumah sakit, penurunan kemampuan fungsional dan terjadinya kematian yang lebih awal.

Kualitas hidup penderita hipertensi dipengaruhi oleh intensitas kontrol, kepatuhan terhadap terapi antihipertensi, modifikasi pola hidup dan jenis terapi farmakologis yang dikonsumsi (Jachuck et al., 1982; Croog et al.,1986 dalam Lalonde et al., 2004). Saleem et al. (2012) menambahkan bahwa kualitas hidup penderita hipertensi juga dapat dipengaruhi oleh efek samping antihipertensi.

Pengukuran kualitas hidup pada penderita hipertensi dilakukan dengan mengkaji jenis antihipertensi yang dikonsumsi serta efek samping yang ditimbulkan (Handler, 2005). Namun, jenis antihipertensi bukanlah satusatunya faktor utama yang mempengaruhi kualitas hidup penderita. Dalam pengukuran kualitas hidup penderita hipertensi perlu dipertimbangkan berbagai aspek biologis, psikologis, sosial dan kultural (Testa, 2000; Nunes, 2001). Faktorfaktor seperti tingkat pendidikan, status ekonomi, jenis antihipertensi dan dukungan keluarga dapat mempengaruhi kualitas hidup penderita hipertensi. Penelitian yang dilakukan oleh Ucan \& Nimet (2010) menyebutkan bahwa tingkat pendidikan dan status sosial ekonomi yang rendah dapat menurunkan kualitas hidup penderita hipertensi.

Tujuan dari penelitian ini adalah untuk mengidentifikasi faktor-faktor yang mempengaruhi kualitas hidup pasien dengan hipertensi derajat II di Puskesmas Dinoyo Kota Malang.

\section{METODE}

Penelitian ini menggunakan desain analitic-observational dengan metode cross-sectional. Populasi dalam penelitian ini adalah semua pasien hipertensi derajat II yang telah mendapatkan program terapi antihipertensi minimal selama 6 bulan di Poli Umum Puskesmas Dinoyo Kota Malang. Teknik sampling yang digunakan adalah kuota waktu. Pengumpulan data yang dilakukan pada penelitian ini antara lain: kepatuhan terapi, kualitas hidup, dan data demografi responden. Kepatuhan terapi diukur dengan kuisioner MMAS8 (Morisky Medications Adherence Scale-8) dan kualitas hidup diukur dengan kuisioner SF-36 (Short Form-36). 


\section{HASIL PENELITIAN}

Responden yang memenuhi kriteria inklusi dalam penelitian ini berjumlah 50 orang. Pada penelitian ini dilakukan pengkajian karakteristik demografi responden, pengukuran kepatuhan terapi dan kualitas hidup. Table dibawah ini merupakan karakteristik demografi responden.

Tabel 1. Karakteristik Demografi Responden

\begin{tabular}{|c|c|c|c|}
\hline \multirow{2}{*}{ No } & \multirow{2}{*}{ Data Demografi } & \multicolumn{2}{|c|}{ Jumlah } \\
\hline & & $\mathbf{n}$ & $\%$ \\
\hline \multirow[t]{5}{*}{1.} & Kategori Usia: & & \\
\hline & - Dewasa akhir: $<46$ tahun & 2 & 2,9 \\
\hline & - Lansia awal: 46 - 55 tahun & 13 & 26 \\
\hline & - Lansia akhir: 56 - 65 tahun & 22 & 44 \\
\hline & - Manula: $\geq 65$ tahun & 13 & 26 \\
\hline \multirow[t]{4}{*}{2.} & Tingkat pendidikan: & & \\
\hline & - Rendah & 35 & 70 \\
\hline & - Sedang & 13 & 26 \\
\hline & - Tinggi & 2 & 4 \\
\hline \multirow[t]{4}{*}{3.} & Tingkat ekonomi: & & \\
\hline & - Rendah & 8 & 16 \\
\hline & - Sedang & 36 & 72 \\
\hline & - Tinggi & 6 & 12 \\
\hline
\end{tabular}

Karakteristik responden lainnya terkait juga dikaji dan disajikan pada Tabel 2 dengan program terapi antihipertensi sebagai berikut:

Tabel 2. Karakteristik Responden dalam Program Terapi

\begin{tabular}{|c|c|c|c|}
\hline \multirow{2}{*}{ No } & \multirow{2}{*}{ Karakteristik Responden } & \multicolumn{2}{|c|}{ Jumlah } \\
\hline & & $\mathbf{n}$ & $\%$ \\
\hline \multirow[t]{3}{*}{1.} & Jenis terapi antihipertensi: & & \\
\hline & - Kombinasi & 3 & 6 \\
\hline & - Monoterapi & 47 & 94 \\
\hline \multirow[t]{4}{*}{2.} & Antihipertensi monoterapi $(\mathrm{n}=47)$ : & & \\
\hline & - ACEI & 28 & 56 \\
\hline & - $\mathrm{CCB}$ & 16 & 32 \\
\hline & - Diuretik & 3 & 6 \\
\hline \multirow[t]{3}{*}{3.} & Antihipertensi kombinasi $(\mathrm{n}=3)$ : & & \\
\hline & - ACEI dan Diuretik & 2 & 4 \\
\hline & - ACEI dan CCB & 1 & 2 \\
\hline \multirow[t]{3}{*}{4.} & Dukungan keluarga: & & \\
\hline & - Ada & 9 & 18 \\
\hline & - Tidak ada & 41 & 82 \\
\hline \multirow[t]{3}{*}{5.} & Kepatuhan terapi: & & \\
\hline & - Patuh & 12 & 24 \\
\hline & - Tidak Patuh & 38 & 76 \\
\hline \multirow[t]{3}{*}{6.} & Kualitas Hidup: & & \\
\hline & • Baik & 33 & 66 \\
\hline & - Buruk & 17 & 34 \\
\hline
\end{tabular}


Berdasarkan hasil analisis jalur ditemukan bahwa faktor-faktor yang berpengaruh langsung terhadap kualitas hidup berturut-turut adalah kepatuhan terapi $\quad(\mathrm{r}=0.401 ; \mathrm{p}=0.000)$, tingkat ekonomi $(\mathrm{r}=0.257 ; \mathrm{p}=0.009)$ dan jenis antihipertensi $(\mathrm{r}=0.159 ; \mathrm{p}=0.016)$. Berikut ini merupakan hasil analisis jalur pada penelitian ini:

Tabel 3. Hasil Analisis Jalur

\begin{tabular}{|c|c|c|c|c|}
\hline \multirow{3}{*}{$\begin{array}{c}\text { Karakeristik } \\
\text { Responden }\end{array}$} & \multicolumn{4}{|c|}{ Kualitas Hidup } \\
\hline & \multicolumn{2}{|c|}{ Pengaruh Tunggal } & \multicolumn{2}{|c|}{ Pengaruh Kombinasi } \\
\hline & Koefisien & T-Statistik & Koefisien & T-Statistik \\
\hline Kepatuhan Terapi & 0,401 & 3,774 & - & - \\
\hline Antihipertensi & 0,159 & 1,713 & 0,119 & 6,932 \\
\hline Keluarga & 0,282 & 0,888 & 0,403 & 3,802 \\
\hline Usia & $-0,127$ & 1,918 & 0,221 & 5,453 \\
\hline Jenis Kelamin & $-0,009$ & 0,112 & - & - \\
\hline Tk. Pendidikan & $-0,091$ & 1,680 & 0,638 & 5,736 \\
\hline Tingkat Ekonomi & 0,257 & 2,344 & 0,640 & 6,467 \\
\hline
\end{tabular}

\section{PEMBAHASAN}

Kepatuhan terapi memiliki hubungan yang bermakna terhadap kualitas hidup pasien dengan hipertensi derajat II. Semakin tidak patuh pasien terhadap program pengobatan maka kualitas hidup pasien semakin buruk. Pernyataan tersebut sesuai dengan hipotesis penelitian bahwa semakin patuh seseorang terhadap program terapi maka akan semakin baik pula kualitas hidupnya. Beberapa penelitian yang menunjukkan hubungan antara kepatuhan terapi dan kualitas hidup antara lain: Bailey et al. (2010) membuktikan bahwa kepatuhan pasien hipertensi dalam program terapi mampu meningkatkan kualitas hidup dengan mengurangi resiko terjadinya stroke sebesar $8-9 \%$ serta dapat mengurangi resiko terjadinya kematian sebesar 7\%. Aguwa et al., 2008 menyimpulkan bahwa pasien dengan tingkat kepatuhan tinggi memiliki rata-rata skor kualitas hidup yang lebih baik dibandingkan kelompok yang lain, terutama rata-rata skor pada domain fisik dan sosial.

\section{Hubungan antara Kepatuhan Terapi terhadap Kualitas Hidup Pasien Hipertensi Derajat II}

Hasil analisis menunjukkan bahwa kepatuhan terapi memiliki hubungan yang bermakna terhadap kualitas hidup dengan nilai $p$-value $0,000 \quad(p<0,05)$. Kepatuhan terhadap program terapi memberikan pengaruh positif terhadap kualitas hidup sebesar 0,401 dengan T-hitung $=3,774(\mathrm{~T}$ hitung>T-tabel). Semakin tinggi tingkat kepatuhan terhadap program terapi maka semakin baik pula kualitas hidup pasien dengan hipertensi derajat II. Hasil analisis juga menunjukkan bahwa penderita hipertensi derajat II dengan tingkat kepatuhan rendah beresiko 7.5 kali memiliki kualitas hidup buruk dibandingkan penderita hipertensi dengan tingkat kepatuhan tinggi.

Hipertensi sering dikaitkan dengan kualitas hidup yang rendah serta menjadi faktor resiko utama terjadinya penyakit kardiovaskular lain. Tekanan darah yang tinggi pada penderita hipertensi tidak terkontrol 
dalam jangka waktu lama dapat merusak endhotel arteri dan menimbulkan gangguan pada berbagai organ tubuh. Hipertensi dapat mengakibatkan arteriosklerosis dan mempercepat terjadinya aterosklerosis. Kondisi tersebut dalam jangka panjang dapat menghasilkan gaya regang yang mengakibatkan lapisan endotel arteri robek dan beresiko menimbulkan stroke.

Konsumsi antihipertensi secara teratur dapat menurunkan tekanan darah melalui mekanisme yang unik sesuai dengan jenis terapi yang dikonsumsi (Depkes, 2006). Kepatuhan dalam mengkonsumsi antihipertensi membantu mengontrol tekanan darah dalam kondisi stabil dan mencegah terjadinya komplikasi lanjut.

\section{Hubungan antara Tingkat}

\section{Pendidikan terhadap Kualitas Hidup} Pasien Hipertensi Derajat II

Dari hasil uji statistic, diperoleh nilai $\mathrm{p}=0,018 \quad(\mathrm{p}<0,05)$ maka dapat disimpulkan terdapat hubungan yang bermakna antara tingkat pendidikan terhadap kualitas hidup pada pasien dengan hipertensi derajat II. Tingkat pendidikan berpengaruh secara positif terhadap kepatuhan terapi sebesar 0,237 (T-hitung=1,962) bermakna bahwa semakin tinggi tingkat pendidikan seseorang maka semakin tinggi tingkat kepatuhan terhadap program terapi. Hasil analisis jalur juga menunjukkan bahwa tingkat pendidikan berpengaruh negatif sebesar -0,091 (T-hitung=1,680) yang bermakna bahwa semakin tinggi tingkat pendidikan seseorang maka persepsi terhadap kualitas hidup akan semakin buruk. Selain itu, hasil analisis juga menunjukkan bahwa penderita hipertensi derajat II dengan tingkat pendidikan tinggi beresiko 5,2 kali memiliki kualitas hidup buruk dibandingkan penderita hipertensi dengan tingkat pendidikan rendah.

Karo (2010) menyebutkan bahwa tingkat pendidikan seseorang berbanding lurus dengan kemampuan untuk mencari sumber informasi kesehatan. Akses yang mudah terhadap informasi kesehatan berperan dalam menciptakan pola hidup seseorang dimana kondisi ini secara tidak langsung dapat mempengaruhi kualitas hidup. Hasil penelitian yang dilakukan oleh Karo (2010) diatas sesuai dengan hasil analisis dalam penelitian ini dimana $65.5 \%$ responden dengan tingkat pendidikan rendah memiliki kualitas hidup yang buruk. Pengetahuan pasien yang baik terhadap proses penyakit hipertensi juga berhubungan erat terhadap kepatuhan terapi dan kualitas hidup pasien (Hareri et al., 2013).

\section{Hubungan antara Tingkat Ekonomi terhadap Kualitas Hidup Pasien Hipertensi Derajat II}

Hasil uji statistik diperoleh nilai $\mathrm{p}=0,001 \quad(\mathrm{p}<0,05) \quad$ maka dapat disimpulkan terdapat hubungan yang bermakna antara tingkat ekonomi terhadap kualitas hidup pada pasien dengan hipertensi derajat II. Tingkat ekonomi memberikan pengaruh positif secara langsung baik terhadap kepatuhan terapi $(0,239)$ maupun terhadap kualitas hidup $(0,257)$. Hal ini bermakna bahwa semakin tinggi tingkat ekonomi responden maka semakin baik pula kepatuhan terhadap program terapi dan kualitas hidupnya. 
Pada analisis tidak langsung diperoleh nilai koefisien korelasi sebesar 0,640 (T-hitung=6,467) yang bermakna bahwa kombinasi antara kepatuhan terhadap program terapi dan dukungan ekonomi mampu berpengaruh terhadap kualitas hidup sebesar 0,640. Koefisien korelasi yang dihasilkan merupakan koefisien terbesar dalam model persamaan menunjukkan bahwa unsur penting dalam mencapai kualitas hidup yang baik adalah kepatuhan terapi yang didukung oleh kemampuan ekonomi responden.

Hasil

analisis

bahwa

menunjukkan

hipertensi derajat II dengan tingkat ekonomi rendah beresiko 4,7 kali memiliki kualitas hidup buruk dibandingkan penderita hipertensi dengan tingkat ekonomi tinggi.

Tingkat ekonomi akan berpengaruh terhadap keseluruhan kondisi kehidupan dan kualitas hidup seseorang (Karo, 2010). Hipertensi kronis memerlukan kontrol terapi seumur hidup yang harus didukung dengan kemampuan ekonomi yang baik. Kemampuan penderita hipertensi dalam membeli obat dan melakukan kontrol rutin berdampak secara langsung terhadap kualitas hidup (Saleem, 2012). Responden dengan tingkat ekonomi rendah mengalami kesulitan dalam melakukan kontrol rutin dan membeli obat antihipertensi. Kondisi tersebut berdampak secara langsung terhadap kualitas hidup pasien. Pasien hipertensi dengan kontrol terapi yang buruk beresiko mengalami komplikasi lanjut pada berbagai organ tubuh.

\section{Hubungan antara Jenis}

Antihipertensi terhadap Kualitas

Hidup Pasien Hipertensi Derajat II

Hasil analisis menunjukkan bahwa jenis antihipertensi berpengaruh positif dan signifikan terhadap kualitas hidup pasien sebesar 0,159 dengan T-hitung=1,713 (Thitung $>$ T-tabel). Pasien dengan terapi kombinasi minimal dua jenis antihipertensi memiliki rata-rata skor kualitas hidup yang lebih baik dibandingkan pasien dengan monoterapi. Namun hasil analisis juga menunjukkan bahwa jenis antihipertensi berpengaruh negatif terhadap kepatuhan terapi sebesar 0,282 dengan T-hitung=3,158 (Thitung>T-tabel). Hal ini bermakna bahwa semakin banyak jenis antihipertensi yang harus dikonsumsi pasien maka semakin rendah tingkat kepatuhan terhadap program terapi. Hasil analisis tidak langsung menunjukkan bahwa kombinasi antara kepatuhan terapi dan pilihan jenis antihipertensi yang tepat berpengaruh terhadap kualitas hidup sebesar 0,119 (T-hitung=6,932) (T-hitung $>$ T-tabel). Hasil analisis juga menunjukkan bahwa penderita hipertensi derajat II dengan antihipertensi tunggal beresiko 2,8 kali memiliki kualitas hidup buruk dibandingkan penderita hipertensi dengan antihipertensi kombinasi.

Kualitas hidup pasien hipertensi dapat dipengaruhi oleh efek samping terapi antihipertensi. Tiap jenis antihipertensi memiliki efek terapeutik menurunkan tekanan darah melalui mekanisme yang berbeda namun disisi lain antihipertensi juga dapat menimbulkan efek samping tertentu pada pasien. Efek samping 
yang ditimbulkan oleh antihipertensi yang dikonsumsi pasien dapat mengakibatkan penurunan kualitas hidup pasien (Horne et al., 2001). Oleh karena itu dalam program medikasi hipertensi digunakan teknik kombinasi antihipertensi dosis rendah dengan efek terapi maksimal dan efek samping minimal (Handler, 2005).

Pasien dengan terapi kombinasi ACEI dan diuretik menunjukkan ratarata skor kualitas hidup paling baik diantara terapi antihipertensi yang lain yaitu 57,00. Menurut JNC 7 kombinasi antara ACEI dan diuretik merupakan salah satu terapi kombinasi yang paling efektif. Terapi kombinasi ini dianjurkan karena memiliki efek sinergisme dan mampu menurunkan efek samping terapi.

\section{Hubungan antara Dukungan Keluarga terhadap Kualitas Hidup Pasien Hipertensi Derajat II}

Hasil analisis menunjukkan bahwa tidak terdapat hubungan antara dukungan keluarga terhadap kualitas hidup pada pasien dengan hipertensi derajat II $\quad(p=0,285)$. Dukungan keluarga juga tidak berpengaruh secara signifikan terhadap kualitas hidup (T-hitung<T-tabel). Namun, hasil analisis hubungan tidak langsung menunjukkan bahwa kombinasi antara kepatuhan terhadap program terapi dan dukungan yang diberikan dalam proses pengobatan mampu berpengaruh secara signifikan terhadap kualitas hidup pasien sebesar 0,403 ( $\mathrm{T}=3,802)$. Hasil analisis juga menunjukkan bahwa penderita hipertensi derajat II tanpa dukungan keluarga beresiko 1,2 kali memiliki kualitas hidup buruk dibandingkan penderita hipertensi derajat II yang mendapat dukungan keluarga.

Hasil analisis diatas sesuai dengan penelitian yang dilakukan oleh Hassan et al. (2006) yang menyebutkan bahwa tidak terdapat hubungan yang bermakna antara motivasi lingkungan sosial pasien terhadap kepatuhan dan kualitas hidup pasien dengan hipertensi. Penelitian yang dilakukan pada kelompok masyarakat keturunan Africa-America juga menunjukkan bahwa dukungan sosial yang diberikan kepada penderita hipertensi tidak berhubungan dengan hipertensi $(\mathrm{p}=0,066)$ (Heard et al., 2011).

Dukungan yang diberikan oleh tenaga kesehatan memberikan dampak yang lebih bermakna dibandingkan dukungan yang diberikan oleh keluarga pasien maupun lingkungan sosial pasien lainnya. Kualitas komunikasi dan hubungan tenaga kesehatan-pasien yang baik meningkatkan kepatuhan pasien terhadap program terapi. Kepercayaan pasien terhadap tenaga kesehatan merupakan salah satu faktor terpenting dalam proses tersebut (Levesque et al., 2012).

Motivasi, dukungan, keyakinan dan empati menjadi landasan penting dalam proses komunikasi antara pasien dan tenaga kesehatan (Chobanian et al., 2003). Dukungan yang diberikan oleh tenaga kesehatan berupa pemberian konseling, informasi dan edukasi tentang proses pengobatan hipertensi memberikan dampak yang lebih baik dibandingkan dengan dukungan keluarga ataupun lingkungan sosial lainnya. 
Hubungan antara Usia terhadap Kualitas Hidup Pasien Hipertensi Derajat II

Hasil analisis menunjukkan bahwa usia memiliki hubungan yang bermakna terhadap kualitas hidup $(p=0,041)$. Usia berpengaruh secara negatif $(-0,127)$ dan signifikan (Thitung $>$ T-tabel) terhadap kualitas hidup. Responden dengan kategori usia lebih lanjut memiliki rata-rata kualitas hidup yang lebih buruk dibandingkan dengan responden yang lebih muda. Analisis hubungan tidak langsung antara usia dan kepatuhan terapi terhadap kualitas hidup menunjukkan bahwa pasien lanjut usia yang patuh terhadap program terapi memberikan pengaruh positif sebesar 0,221 (T-hitung=5,435) terhadap kualitas hidup. Hasil analisis juga menunjukkan bahwa penderita hipertensi derajat II dengan usia lanjut beresiko 2,5 kali memiliki kualitas hidup buruk dibandingkan penderita hipertensi yang berusia lebih muda.

Usia berkaitan erat dengan proses degeneratif dan penurunan fungsi tubuh. Seseorang berusia lanjut akan mengalami peningkatan tekanan darah secara progresif seiring dengan bertambahnya umur. Seseorang dengan normotensi juga akan beresiko mengalami hipertensi pada usia lebih dari 55 tahun sebesar 90\% (Chobanian et al., 2003). Proses degeneratif normal yang diperderajat II dengan terjadinya hipertensi pada responden membuat kualitas hidup pasien menurun secara keseluruhan. Namun analisis hubungan tidak langsung terhadap kualitas hidup membuktikan bahwa proses degeneratif yang dialami oleh responden jika dipadukan dengan kepatuhan dalam menjalankan program terapi maka dapat memberikan pengaruh positif terhadap program terapi. Oleh karena itu, kepatuhan terhadap program terapi merupakan unsur terpenting dalam mencapai kualitas hidup yang baik pada pasien lanjut usia.

\section{Hubungan antara Jenis Kelamin terhadap Kualitas Hidup Pasien Hipertensi Derajat II}

Hasil analisis pada penelitian ini menunjukkan bahwa jenis kelamin memiliki hubungan yang tidak bermakna terhadap kualitas hidup $(p=0,771)$. Jenis kelamin berpengaruh secara negatif $(-0,009)$ dan tidak signifikan (T-hitung<T-tabel) terhadap kualitas hidup. Responden berjenis kelamin perempuan memiliki rata-rata kualitas hidup yang lebih buruk dibandingkan dengan responden lakilaki. Hasil analisis juga menunjukkan bahwa penderita hipertensi derajat II berjenis kelamin perempuan beresiko 0,9 kali memiliki kualitas hidup buruk dibandingkan penderita hipertensi berjenis kelamin laki-laki.

Pada usia dewasa muda hipertensi banyak terjadi pada laki-laki namun setelah usia 55 tahun hipertensi lebih banyak terjadi pada perempuan. Menurut WHO (2012) pada usia dini tidak didapatkan adanya perbedaan tekanan darah antara laki-laki dan perempuan. Namun mulai pada masa remaja, laki-laki cenderung menunjukkan rata-rata tekanan darah yang lebih tinggi. Pada lansia, perbedaan ini berbalik, perubahan ini terjadi karena dengan tingkat kematian awal lebih tinggi pada pria setengah baya pasien hipertensi, selain itu 
perubahan pasca menopause pada perempuan bisa pula berpengaruh (WHO, 2012).

Jumlah responden laki-laki dan perempuan yang sama dalam penelitian ini tidak menunjukkan bahwa mayoritas penderita hipertensi derajat II pada lansia adalah perempuan. Secara statistik dapat diketahui bahwa jenis kelamin tidak berhubungan secara bermakna terhadap kualitas hidup. Namun, jika dilakukan penghitungan rata-rata skor kualitas hidup maka dapat diketahui bahwa responden dengan jenis kelamin perempuan memiliki rata-rata skor kualitas hidup yang lebih rendah.

Dari berbagai penjelasan diatas dapat disimpulkan bahwa perempuan lanjut usia beresiko memiliki kualitas hidup yang buruk dibandingkan jenis kelamin laki-laki. Perubahan hormonal pasca menopause dan angka harapan hidup yang lebih tinggi pada perempuan menjadi penyebab kondisi tersebut. Hal ini tidak berarti bahwa laki-laki lanjut usia tidak beresiko memiliki kualitas hidup yang buruk. Oleh karena itu, program terapi pada pasien dengan hipertensi derajat II yang diberikan oleh tenaga kesehatan harus memperhatikan perubahan hormonal pada perempuan pasca menopause.

\section{Model Persamaan pada Analisis Jalur}

Penelitian ini merupakan penelitian analisis jalur dengan variabel utama kepatuhan terapi dan kualitas hidup pasien hipertensi derajat II. Tujuan utama analisis ini adalah mengetahui hubungan antara kepatuhan terapi terhadap kualitas hidup baik secara langsung maupun tidak langsung dengan melibatkan karakteristik responden lainnya. Model persamaan akhir menunjukkan bahwa kualitas hidup pada pasien dengan hipertensi derajat II dipengaruhi oleh kepatuhan terapi, tingkat pendidikan, tingkat ekonomi, jenis antihipertensi dan usia pasien. Kepatuhan terapi, tingkat ekonomi dan jenis antihipertensi yang dikonsumsi masing-masing berpengaruh secara positif terhadap kualitas hidup. Sedangkan usia dan tingkat pendidikan berpengaruh secara negatif terhadap kualitas hidup. Hasil analisis pada variabel kualitas hidup menunjukkan nilai koefisien determinasi 39,4\% yang bermakna bahwa kualitas hidup dipengaruhi oleh karakteristik responden yang terdapat dalam model penelitian sebesar 39,4\% dan selebihnya yaitu $60,6 \%$ dipengaruhi oleh faktor lain yang tidak terdapat dalam model. Model yang dibuat dalam penelitian ini termasuk dalam kategori moderat karena memiliki nilai koefisien determinasi $<60 \%$ (Wiyono, 2011). Rendahnya nilai koefisien determinasi dalam penelitian ini disebabkan oleh variabel kepatuhan terhadap terapi non-farmakologis yang tidak dimasukkan dalam pemodelan akhir.

Melalui proses analisis hubungan secara langsung terhadap kualitas hidup maka diperoleh model persamaan sebagai berikut:

QoL $=(0,401 \times$ Patuh $)+(-0,091 \times$ Edu $)+(0,257 \times$ Eco $)$ $+(0,159 \times \mathrm{AH})+(-0,127 \times$ Age $)$

Model persamaan menunjukkan bahwa kepatuhan terhadap program terapi merupakan salah satu 
komponen terpenting dalam tercapainya kualitas hidup yang baik pada pasien dengan hipertensi derajat II. Hal ini ditunjukkan dengan adanya nilai koefisien korelasi kepatuhan terapi $(0,401)$ yang paling besar dibandingkan dengan koefisien korelasi variabel yang lainnya. Kepatuhan terapi berpengaruh secara positif terhadap kualitas hidup. Pernyataan tersebut sesuai dengan hipotesis penelitian bahwa semakin patuh seseorang terhadap program terapi maka akan semakin baik pula kualitas hidupnya. Beberapa penelitian yang menunjukkan hubungan antara kepatuhan terapi dan kualitas hidup antara lain: Bailey et al. (2010) membuktikan bahwa kepatuhan pasien hipertensi dalam program terapi mampu meningkatkan kualitas hidup dengan mengurangi resiko terjadinya stroke sebesar $8-9 \%$ serta dapat mengurangi resiko terjadinya kematian sebesar 7\%. Papp et al. (2012) menyebutkan bahwa kepatuhan terhadap terapi pada pasien hipertensi dapat menurunkan resiko kematian akibat stroke. Aguwa et al., 2008 menyimpulkan bahwa pasien dengan tingkat kepatuhan tinggi memiliki rata-rata skor kualitas hidup yang lebih baik dibandingkan kelompok yang lain, terutama rata-rata skor pada domain fisik dan sosial.

Karakteristik responden yang masuk dalam model persamaan kualitas hidup antara lain: tingkat pendidikan, tingkat ekonomi, jenis antihipertensi dan usia pasien. Tingkat ekonomi $(0,257)$ dan jenis antihipertensi $(0,159)$ berpengaruh secara positif terhadap kualitas hidup pasien hipertensi derajat II. Semakin tinggi tingkat ekonomi dan semakin tepat jenis antihipertensi yang diberikan kepada pasien maka akan semakin baik pula kualitas hidupnya. Sedangkan tingkat pendidikan $(-0,091)$ dan usia $(-0,127)$ berpengaruh secara negatif terhadap kualitas hidup pasien. Semakin tinggi dan semakin lanjut usia pasien maka kualitas hidup pasien akan semakin buruk.

Berikut ini akan dijelaskan bagaimana peran karakteristik responden dalam model akhir persamaan. Melalui proses analisis dapat diketahui bahwa tingkat pendidikan dapat mempengaruhi kepatuhan terapi maupun kualitas hidup. Tingkat pendidikan menggambarkan kemampuan kognitif individu dalam menerima informasi, semakin tinggi tingkat pendidikan seseorang maka kemampuan kognitif dalam menerima informasi akan semakin baik. Informasi mengenai proses penyakit dan pengobatan yang sedang dijalani dapat meningkatkan kepatuhan pasien terhadap program terapi.

Tingkat pendidikan juga dapat mempengaruhi kualitas hidup seseorang, semakin tinggi tingkat pendidikan seseorang maka semakin rendah tingkat kepuasan dalam kehidupan. Tingkat ekonomi mempengaruhi secara langsung kepatuhan terapi dan kualitas hidup karena berkaitan dengan kemampuan individu dalam membeli obat dan melakukan kontrol secara rutin. Begitupula dengan jenis antihipertensi yang memiliki hubungan terhadap kepatuhan terapi dan kualitas hidup. Semakin sedikit jumlah obat yang harus dikonsumsi maka semakin 
tinggi tingkat kepatuhan pasien terhadap program terapi. Terapi kombinasi dosis minimal dengan efek sinergis dapat mengurangi efek samping dan meningkatkan kualitas hidup penderita hipertensi. Sedangkan usia dapat berpengaruh secara negatif terhadap kepatuhan terapi maupun kualitas hidup pasien dengan hipertensi derajat II. Seiring bertambahnya usia maka terjadi proses degeneratif alami pada pasien. Kepatuhan terhadap program terapi memerlukan kemampuan kognitif untuk mengingat dosis dan waktu konsumsi obat. Pasien lanjut usia rentan lupa terhadap kewajiban untuk minum obat secara teratur. Selain itu proses penuaan secara alami juga dapat menurunkan kualitas hidup seseorang bahkan pada seorang lansia dengan normotensi sekalipun.

Analisis secara tidak langsung terhadap kualitas hidup menunjukkan bahwa kombinasi antara kepatuhan terapi dan karakteristik positif responden lainnya mampu meningkatkan kualitas hidup pasien lebih baik dibandingkan intervensi tunggal. Seluruh koefisien korelasi menunjukkan hubungan yang lebih positif terhadap kualitas hidup jika dikombinasikan dengan kepatuhan terapi. Hal ini menunjukkan bahwa kepatuhan terapi merupakan komponen penting dalam tercapainya kualitas hidup yang baik pada pasien hipertensi derajat II.

Dari penjelasan diatas dapat disimpulkan bahwa untuk mencapai kualitas hidup yang baik pada pasien hipertensi derajat II maka dilakukan modifikasi pada variabel yang masuk dalam model persamaan yaitu kepatuhan terapi, tingkat pendidikan, tingkat ekonomi, jenis antihipertensi. Kepatuhan terhadap program terapi demi tercapainya kualitas hidup yang baik dapat dilakukan melalui beberapa cara berikut ini: meningkatkan pengetahuan pasien tentang hipertensi dan proses pengobatannya, serta memberikan jenis antihipertensi kombinasi dengan harga yang terjangkau bagi pasien.

\section{KESIMPULAN}

Kualitas hidup pada pasien dengan hipertensi derajat II dipengaruhi oleh kepatuhan terapi, tingkat pendidikan, tingkat ekonomi, jenis antihipertensi dan usia pasien. Kepatuhan terapi, tingkat ekonomi dan jenis antihipertensi yang dikonsumsi masing-masing berpengaruh secara positif terhadap kualitas hidup. Sedangkan usia dan tingkat pendidikan berpengaruh secara negatif terhadap kualitas hidup. Faktor ekonomi dan pendidikan merupakan faktor yang paling dominan dalam menentukan kepatuhan terapi yang kemudian berdampak kepada kualitas hidup.

\section{DAFTAR PUSTAKA}

Aguwa, C.N., Ukwe, C.V., Ekwunife, O.I 2008. Effect of Pharmaceutical Care Prograamme on Blood Pressure and Quality of Life in a Nigerian Pharmacy. Pharm World Sci (30): 107-110.

Bailey, J.E., Wan, J.Y., Tang, J., Ghani, M.A., Cushman, W.C. 2010. Antihypertensive Medication Adherence, Ambulatory Visits and 
Risk For Stroke and Death. J Gen Intern Med (25)6: 495-503.

Chobanian, A. V. 2003. The Sevent Report of The Joint National Committee on Prevention, Detection, Evaluation and Treatment of High Blood Presurre. Joint National Committee on Prevention, Detection, Evaluation and Treatment of High Blood Presurre. Arch Intern Med.

Departemen Kesehatan Republik Indonesia. 2006. Pharmaceutical Care Untuk Penyakit Hipertensi. Direktorat Bina Farmasi Komunitas Dan Klinik: Ditjen Bina Kefarmasian Dan Alat Kesehatan.

Franklin, S.S. and Neutel, J.M. 2009. Initial Combination Therapy for Rapid and Effective Control of Moderate and Severe Hypertension. Journal of Human Hypertension (23): 4-11.

Hacihasanoglu, R. and Gozum, S. 2011. The Effect of Patients Education and Home Monitoring on Medication Compliance, Hypertension Management, Healthy Lifestyle Behaviours and BMI in a Primary Health Care Setting. Journal of Clinical Nursing (20)5-6: 692-705.

Handler, J. 2005. Quality of Life and Antihypertensive Drug Theraphy. The Journal of Clinical Hypertension (7)5: 274-285.

Hareri, H.A., Abebe, M., Asewaf, T. 2013. Assessment of Adherence To Hypertension Managements and It's Influencing Factors Among Hypertensive Patients Attending Black Lion Hospital Chronic
Follow Up Units, Addis Abbaba, Ethiopia, A Cross Sectional Study. IJPSR (4)3: 1086-1095.

Hassan, N.B., Hasanah, C.I., Foong, K., Naing, L. Awang, R., Ismail, S.B., Ishak, A., Yaacob, L.H., Harmy, M.Y., Daud, A.H., Shaharom, M.H., Conroy, R., Rahman, A.R.A. 2006. Identification of Psychosocial Factors of Noncompliance in Hypertensive Patients. Journal of Human Hypertension (20): 23-29.

Heard, E., Whitfield, K.E., Edwards, C.L., Bruce, M.A., Beech, B.M. 2011. Mediating Effects of Social Support on The Relationship Among Perceived Stress, Depression, and Hypertension in Africa Americans. Journal of The National Medical Association (103)2: 116-122.

Horne, R., Clatworthy J., Polmear, A., Weinman, J. 2001. Do Hypertensive Patients Beliefs About Their Illness and Treatment Influence Adherence Medication and Quality of Life. Journal of Human Hypertension (15)1: 65-68.

Iqbal, M. 2011. Clinical Perspective on the Management of Hypertension, Indian Journal of Clinical Medicine (2): 1-17.

Karo, W.S. 2010. Pengaruh Tingkat Pendapatan Terhadap Kualitas Hidup (Studi kasus RW 05 Kelurahan Serdang Kecamatan Kemayoran Jakarta Pusat). Perpustakaan Universitas Indonesia.

Lalonde, L., O'Connor, A., Joseph, L., Grover, S.A. \& The Canadian Collaborative Cardiac Assessment 
Group. 2004. Health-releated Quality of Life in Cardiac Patients with Dyslipidemia and Hypertension. Quality of Life Research (13): 793-804.

Nunes, M.I. 2001. The Relationship Between Quality of Life and Adherence to Treatment. Current Hypertension Report (3): 462-465.

Saleem, F., Hassali, M.A., Shafie, A.A., Awad, G.A., Atif, M., Haq, M., Aljadhey, H., Farooqui, M. 2012. Does Treatment Adherence Correlates with Healt Realeted Quality of Life? Findings from a Cross Sectional Study. BioMed Central (12): 318.

Testa, M.A. 2000. Methods and Applications of Quality-of-Life Measurement During Antihypertensive Therapy. Current Hypertension Reports.

Ucan, O. and Nimet O. 2010. Relationship between Diabetes Mellitus, Hypertension and Obesity, and Health-releated Quality of Life in Gaziantep, a Central South-Eastern City in Turkey. Journal of Clinical Nursing (19): 2511-2519.

Whelton, P.K., J He, Muntner P. 2004. Prevalence, awareness, treatment and control of hypertension in North America, North Africa and Asia, Journal of Human Hypertension (18): 545-551.

WHO. 2012. World Health Statistic New Releases: Hypertension Prevalence.

http://www.who.int/mediacentre/n ews/releases/2012. Diakses pada 2 Maret 2013. 